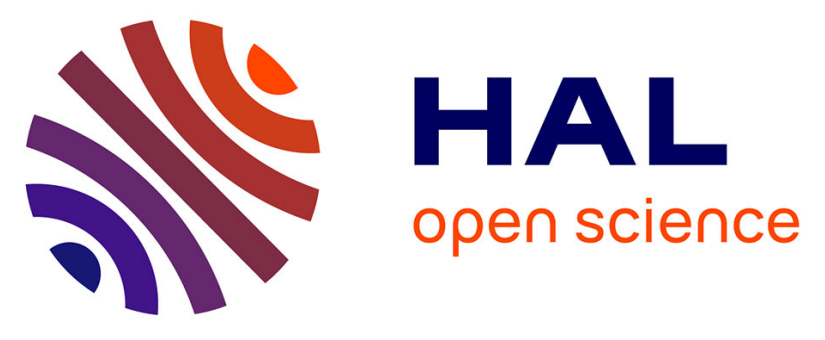

\title{
Multicenter Comparative Assessment of the TIB MolBiol Toxoplasma gondii Detection Kit and Four Laboratory-Developed PCR Assays for Molecular Diagnosis of Toxoplasmosis
}

Marie-Pierre Brenier-Pinchart, Florence Robert-Gangneux, Isabelle Accoceberry, Simon Pichard, Cécile Garnaud, Hélène Fricker-Hidalgo, Maude Lévêque, Gautier Hoarau, Hervé Pelloux, Patrick Bastien, et al.

\section{- To cite this version:}

Marie-Pierre Brenier-Pinchart, Florence Robert-Gangneux, Isabelle Accoceberry, Simon Pichard, Cécile Garnaud, et al.. Multicenter Comparative Assessment of the TIB MolBiol Toxoplasma gondii Detection Kit and Four Laboratory-Developed PCR Assays for Molecular Diagnosis of Toxoplasmosis. Journal of Molecular Diagnostics, 2021, 23 (8), pp.1000-1006. 10.1016/j.jmoldx.2021.05.010 . hal-03282456

\section{HAL Id: hal-03282456 https://hal.science/hal-03282456}

Submitted on 23 Aug 2021

HAL is a multi-disciplinary open access archive for the deposit and dissemination of scientific research documents, whether they are published or not. The documents may come from teaching and research institutions in France or abroad, or from public or private research centers.
L'archive ouverte pluridisciplinaire HAL, est destinée au dépôt et à la diffusion de documents scientifiques de niveau recherche, publiés ou non, émanant des établissements d'enseignement et de recherche français ou étrangers, des laboratoires publics ou privés. 


\title{
Multicenter comparative assessment of the TIB MolBiol ${ }^{\circledR}$ Toxoplasma gondii detection kit and four laboratory-developed PCR assays for molecular diagnosis of toxoplasmosis
}

Marie-Pierre Brenier-Pinchart, ${ }^{1,2}$ Florence Robert-Gangneux, ${ }^{1,3}$ Isabelle Accoceberry ${ }^{4}$ Simon Pichard, ${ }^{4}$ Cécile Garnaud, ${ }^{2}$ Hélène Fricker-Hidalgo ${ }^{2}$, Maude F Lévêque, ${ }^{5}$ Gautier Hoarau, ${ }^{5}$ Hervé Pelloux, ${ }^{1,2}$ Patrick Bastien, ${ }^{1,5}$ Yvon Sterkers, ${ }^{1,5^{*}}$ and Emmanuelle Varlet-Marie, ${ }^{1,6^{*}}$

From the Molecular Biology Pole of the National Reference Center (CNR) for Toxoplasmosis, ${ }^{1}$ "Molecular biology" pole of the National Reference Center (CNR) for Toxoplasmosis, Montpellier, France, ${ }^{2}$ Univ Grenoble Alpes, CHU Grenoble Alpes, Laboratory of Parasitology-Mycology, Grenoble, France, ${ }^{3}$ Univ Rennes, CHU of Rennes, Inserm, EHESP, Irset - UMR_S 1085; Rennes, France, ${ }^{4}$ Laboratory of Parasitology-Mycology, CHU de Bordeaux, France, ${ }^{5}$ Univ Montpellier, CNRS, IRD, CHU of Montpellier, MiVEGEC and Department of Parasitology-Mycology, Montpellier, France, ${ }^{6}$ Univ Montpellier, CHU Montpellier, Department of Parasitology-Mycology, Montpellier, France, * Co-corresponding authors

Mailing address: Département de Parasitologie-Mycologie UMR MIVEGEC Université Montpellier-CNRS-IRD 224 C.H.U. de Montpellier 39 Av. Charles Flahault (site Antonin Balmès) 34295 Montpellier cedex 5, France. Phone: +33-467 3323 50, Fax: +33-467 3323 58. Email addresses : yvon.sterkers@umontpellier.fr, emmanuelle.varlet@umontpellier.fr

This manuscript has been published, please cite: Multicenter Comparative Assessment of the TIB MolBiol Toxoplasma gondii Detection Kit and Four Laboratory-Developed PCR Assays for Molecular Diagnosis of Toxoplasmosis. Brenier-Pinchart MP, Robert-Gangneux F, Accoceberry I, Pichard S, Garnaud C, Fricker-Hidalgo H, Lévêque MF, Hoarau G, Pelloux H, Bastien P, Sterkers Y, Varlet-Marie E. J Mol Diagn. 2021 May 31:S1525-1578(21)00138-0. doi: 10.1016/j.jmoldx.2021.05.010. Online ahead of print. PMID: 34082073

\begin{abstract}
Toxoplasmosis may be a life-threatening infection, particularly in pregnancy and in immunocompromised patients. The biological diagnosis of toxoplasmosis is challenging, and has been revolutionized by molecular detection methods. Here is presented the data of a multicenter study involving four centers to assess the performances of a commercial PCR assay as compared to four in-house PCR assays using Toxoplasma gondii standards, 20 external quality control specimens and 133 clinical samples. This clinical cohort includes well characterized clinical samples corresponding to different clinical situations: confirmed congenital toxoplasmosis (44 samples), toxoplasmosis in immunocompromised patients (25 samples) and chorioretinitis (5 samples). Furthermore, 59 samples from patients without toxoplasmosis were included as negative controls. The analytical sensitivities of the five methods tested were very similar; and the limit of Toxoplasma DNA detection was around $0.01 \mathrm{~T}$. gondii genome per reaction for all the methods. The overall concordance between the commercial PCR and the four in-house PCR assays was $97.7 \%$ (130/133). The clinical sensitivity and specificity were >98\% and could be increased for the commercial kit when PCR was performed in multiplicata to detect low parasitic loads. In conclusion, the commercial PCR assay shows suitable performances to diagnose the different clinical forms of toxoplasmosis.
\end{abstract}

\section{Introduction}

Toxoplasma gondii is a worldwide distributed protozoan parasite causing toxoplasmosis ${ }^{1}$. Human transmission pathways include (i) the consumption of raw/undercooked meat containing cysts or food/water contaminated by oocysts shed in the cats' feces, (ii) vertical transmission of tachyzoites or (iii) the transplant of organ/hematopoietic stem cells containing cysts. The infection is most often asymptomatic in healthy individuals. However, there are two severe clinical issues in Toxoplasma infection: (i) a primary infection occurring in pregnant women may infect the fetus and cause congenital toxoplasmosis (CT), leading to miscarriage, chorioretinis or malformative syndrome; (ii) the reactivation of cysts in previously infected immunocompromised hosts (solid organ transplants, hematopoietic stem cell transplants, AIDS patients) may cause lifethreatening complications such as cerebral or disseminated toxoplasmosis. In both situations, the biological diagnosis is challenging and has greatly beneficiated from molecular methods ${ }^{2,3}$. Currently, molecular detection of Toxoplasma infection relies on laboratory-developed or 'in-house' real time PCR assays ${ }^{4}$. Although they represent sensitive methods 2,3 , they suffer from lack of standardization. Efforts towards Toxoplasma-PCR standardization and quality management include the use of commercialized PCR assays. Their performances, however, are variable and require proper evaluation by expert laboratories ${ }^{5-8}$ - the more so since Toxoplasma parasitic loads in clinical samples are often low, which requires that PCR assays show a 
high sensitivity. For example in CT, the median concentration in the amniotic fluid (AF) has been reported to be around 10 tachyzoites $/ \mathrm{mL}^{9}$. In this study, the technical performances of the TIB MolBiol $^{\circledR}$ LightMix $^{\circledR}$ Kit Toxoplasma gondii PCR assay (Roche ${ }^{\circledR}$, Meylan, France) were compared with those of reference laboratory-developed real time PCR assays in three distinct clinical settings: CT (using amniotic fluid and placenta), toxoplasmic chorioretinitis (using aqueous humor), and toxoplasmic infection in immunocompromised patients (using blood, cerebrospinal fluid and miscellaneous samples).

\section{Materials and methods}

\section{Study scheme}

The study was conducted in accordance with the regulations of the local medical ethics committee of the Hospital University Center (CHU) of Montpellier, France, in line with the revised Helsinki Declaration. Written consent was obtained before any amniotic fluid sampling. This study was performed in the Departments of ParasitologyMycology of four Academic Hospital Centers (Montpellier, Grenoble, Rennes and Bordeaux), hereafter referred as center A, B, C and D respectively. Centers $\mathrm{A}, \mathrm{B}$ and $\mathrm{C}$ are members of the "Molecular Biology Pole" of the French National Reference Center for Toxoplasmosis (http://cnrtoxoplasmose.chu-reims.fr/, last access April 07, 2021). Center D uses the TIB MolBiol® method in routine practice. All four centers are proficient centers for the molecular diagnosis of toxoplasmosis.

The study scheme comprised four parts. The first part aimed at testing the TIB MolBiol ${ }^{\circledR}$ method using simulated calibrated specimens from external quality assessments and was performed by center A. The second part of the study consisted in determining PCR efficiencies and analytical sensitivities based on serial dilution assays using two standards for Toxoplasma detection and was performed by centers A and B. The third part aimed at testing clinical samples and involved the four centers. The results obtained using TIB MolBiol ${ }^{\circledR}$ were compared with those obtained in routine in each center. The fourth part is a prospective study performed by center $\mathrm{D}$.

\section{Lyophilized standards and external} Quality Control samples

Two standards were used for the molecular detection of Toxoplasma. The first one was a standard described by Varlet-Marie et al. ${ }^{10}$, based on a 10-fold serial dilution assay to include six concentrations ranging from 10,000 to $0.1 \mathrm{~T}$. gondii per $\mathrm{mL}$. The second one was the DNA standard provided by the commercial kit, which includes a row of six standards ranging from $10^{6}$ to 10 target molecules per PCR tube. In both cases, each serial dilution concentration was tested in triplicate. The TIB MolBiol $^{\circledR}$ assay was performed with and without the internal control provided by the manufacturer. Twenty external Quality Control samples, 13 positive and 7 negative samples, were also included.

\section{Clinical samples}

In total, 133 clinical samples were included in the study, collected within the frame of routine practice of the four participating centers. They comprised 76 AF, 16 placenta, 14 whole blood, 6 aqueous humor, 7 cerebrospinal fluid (CSF), 8 bronchoalveolar lavage fluid (BALF), 5 tissue biopsy and 1 lymph node puncture samples. In total, 73 positive and 60 negative samples were included. CT cases were clinically classified as defined by the European Research Network on Congenital Toxoplasmosis group ${ }^{11}$. Cases of toxoplasmosis in immunocompromised patients were assessed according to the European Group for Blood and Marrow Transplantation Infectious Diseases Working Party classification 12, allowing the distinction between Toxoplasma infection and disease. Ocular toxoplasmosis was also confirmed using a comparative Toxoplasma western blot (LDBio Diagnostics, Lyon, France) ${ }^{13}$.

\section{DNA extraction}

The DNA extraction procedure was adapted to the specimens. Center A used the Tween-Nonidet$\mathrm{NaOH}$ method for the paucicellular fluids (AF, aqueous humor and CSF), as previously described 14 and a protein precipitation method for tissues and cellular specimens (whole blood, cord blood, and placenta). Briefly, placenta/tissues were ground, trypsinized, filtered, washed, and lysed with proteinase K (Euromedex ${ }^{\circledR}$, Souffelweyersheim, France) in Tris-SDS $(2-3 \mu \mathrm{L} / 100 \mu \mathrm{L}$ of final solution); buffy coat fractions $(300 \mu \mathrm{L})$, isolated from cord blood and whole blood specimens after centrifugation for $10 \mathrm{~min}$ at $1750 \mathrm{~g}$, were also lysed with proteinase K. DNA was prepared with the protein precipitation solution kit (A795A; Promega ${ }^{\circledR}$, Charbonnières-les-Bains, France) ${ }^{2}$. Centers B and C used DNA minikit (\#51304; Qiagen ${ }^{\circledR}$, Courtaboeuf, France) and center D used the Roche® MagNApure Compact as described by the manufacturers. According to previous published data, DNA extracts were kept frozen at $-20^{\circ} \mathrm{C}$ until the study ${ }^{15}$ (Table 1). 
Table 1. Routine PCR assays characteristics in the four participating centers

\begin{tabular}{|c|c|c|c|c|}
\hline \multirow[b]{2}{*}{ Extraction } & Center A & Center B & Center C & Center D \\
\hline & $\begin{array}{l}\text { "TNN" thermolysis }{ }^{14 a} \text { or } \\
\text { "Promega" protein } \\
\text { precipitation method }{ }^{2 b}\end{array}$ & Qiagen ${ }^{\circledR}$ DNA minikit & & $\begin{array}{l}\text { Roche }{ }^{\circledR} \\
\text { Compact }^{c}\end{array}$ \\
\hline PCR & Reischl et al. ${ }^{17}$ & Reischl et al. $^{17}$ & $\begin{array}{l}\text { Robert-Gangneux et } \\
\text { al. }{ }^{18}\end{array}$ & Costa et al. ${ }^{19}$ \\
\hline Thermocycler & 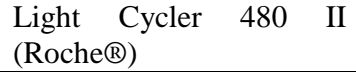 & $\begin{array}{l}\text { Light Cycler } 2.0 \\
\text { (Roche }())\end{array}$ & $\begin{array}{l}\text { Light Cycler } 480 \\
\left.\text { (Roche }{ }^{\circledR}\right)\end{array}$ & Light Cycler 2.0 (Roche $\left.{ }^{\circledR}\right)$ \\
\hline PCR mix & $\begin{array}{l}\text { LightCycler® } 480 \text { Probes } \\
\text { Master (\#04707494001) }\end{array}$ & $\begin{array}{l}\text { Light Cycler }{ }^{\circledR} \\
\text { FastStart DNA Master } \\
\text { HybProbe } \\
(\# 03003248001)\end{array}$ & $\begin{array}{l}\text { Taqman Universal } \\
\text { Master } \quad \text { Mix } \\
\text { (\#4305719; Applied } \\
\text { Biosystems, } \\
\text { Villebon-sur- } \\
\text { Yvette) }\end{array}$ & $\begin{array}{l}\text { Light } \text { Cycler }{ }^{\circledR} \text { FastStart } \\
\text { DNA Master HybProbe } \\
(\# 03003248001)\end{array}$ \\
\hline
\end{tabular}

Table 2. Comparison of routine and TIB MolBiol ${ }^{\circledR}$ methods using serial dilutions of the standard of the National Reference Center for Toxoplasmosis

\begin{tabular}{|c|c|c|c|c|c|c|c|c|}
\hline & & $\begin{array}{l}\text { Concentration } \\
(\mathrm{T} / \mathrm{mL})\end{array}$ & 10,000 & 1000 & 100 & 10 & 1 & 0.1 \\
\hline \multirow[b]{3}{*}{ 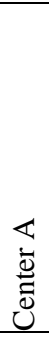 } & $\begin{array}{l}\text { Routine } \\
\mathrm{Eff}=94 \% \\
\mathrm{R}^{2}=0.97\end{array}$ & $\begin{array}{l}\mathrm{N} \\
\mathrm{Cp} \text { mean } \pm \mathrm{sd}{ }^{1}\end{array}$ & $\begin{array}{l}6 / 6 \\
19.7 \pm 0.3\end{array}$ & $\begin{array}{l}6 / 6 \\
23.5 \pm 0.6\end{array}$ & $\begin{array}{l}6 / 6 \\
26.7 \pm 0.5\end{array}$ & $\begin{array}{l}6 / 6 \\
29.6 \pm 0.8\end{array}$ & $\begin{array}{l}6 / 6 \\
32.8 \pm 1.2\end{array}$ & $\begin{array}{l}4 / 6 \\
35.6 \pm 1.9\end{array}$ \\
\hline & $\begin{array}{l}\text { TIB MolBiol with IC } \\
\text { Eff }=99 \% \\
\mathrm{R}^{2}=0.96\end{array}$ & $\begin{array}{l}\mathrm{N} \\
\mathrm{Cp} \text { mean } \pm \text { sd } \\
\text { IC Cp mean } \pm \text { sd }\end{array}$ & $\begin{array}{l}6 / 6 \\
20.0 \pm 0.1 \\
\text { Neg }\end{array}$ & $\begin{array}{l}6 / 6 \\
24.0 \pm 0.1 \\
27.3 \pm 0.4\end{array}$ & $\begin{array}{l}6 / 6 \\
27.4 \pm 0.1 \\
26.6 \pm 0.1\end{array}$ & $\begin{array}{l}6 / 6 \\
30.6 \pm 0.3 \\
27.1 \pm 0.1\end{array}$ & $\begin{array}{l}5 / 6 \\
33.1 \pm 2.1 \\
27.7 \pm 0.1\end{array}$ & $\begin{array}{l}1 / 6 \\
35.9 \\
27.7 \pm 0.1\end{array}$ \\
\hline & $\begin{array}{l}\text { TIB MolBiol w/o IC } \\
\text { Eff }=90 \% \\
\mathrm{R}^{2}=0.99\end{array}$ & $\begin{array}{l}\mathrm{N} \\
\mathrm{Cp} \text { mean } \pm \text { sd }\end{array}$ & $\begin{array}{l}6 / 6 \\
19.8 \pm 0.1\end{array}$ & $\begin{array}{l}6 / 6 \\
23.9 \pm 0.1\end{array}$ & $\begin{array}{l}6 / 6 \\
27.8 \pm 0.2\end{array}$ & $\begin{array}{l}6 / 6 \\
31.5 \pm 0.3\end{array}$ & $\begin{array}{l}4 / 6 \\
33.9 \pm 0.4\end{array}$ & $\begin{array}{l}1 / 6 \\
35.3\end{array}$ \\
\hline \multirow[b]{2}{*}{ 离 } & $\begin{array}{l}\text { Routine } \\
E f f=94 \% \\
R^{2}=0.99\end{array}$ & $\begin{array}{l}\mathrm{N} \\
\mathrm{Cp} \text { mean } \pm \text { sd }\end{array}$ & $\begin{array}{l}3 / 3 \\
21.0 \pm 0.2\end{array}$ & $\begin{array}{l}3 / 3 \\
24.1 \pm 0.2\end{array}$ & $\begin{array}{l}3 / 3 \\
27.1 \pm 0.1\end{array}$ & $\begin{array}{l}3 / 3 \\
30.4 \pm 0.5\end{array}$ & $\begin{array}{l}3 / 3 \\
33.8 \pm 1.1\end{array}$ & $\begin{array}{l}1 / 3 \\
35\end{array}$ \\
\hline & $\begin{array}{l}\text { TIB MolBiol with IC } \\
\text { Eff }=93 \% \\
\mathrm{R}^{2}=0.98\end{array}$ & $\begin{array}{l}\mathrm{N} \\
\mathrm{Cp} \text { mean } \pm \text { sd } \\
\text { IC Cp mean } \pm \text { sd } \\
\end{array}$ & $\begin{array}{l}3 / 3 \\
20.7 \pm 0.2 \\
\text { Neg }\end{array}$ & $\begin{array}{l}3 / 3 \\
23.7 \pm 0.4 \\
\mathrm{Neg}\end{array}$ & $\begin{array}{l}3 / 3 \\
26.6 \pm 0.8 \\
27.0 \pm 0.1 \\
\end{array}$ & $\begin{array}{l}3 / 3 \\
30.1 \pm 0.7 \\
28.9 \pm 0.1 \\
\end{array}$ & $\begin{array}{l}3 / 3 \\
33.4 \pm 1.6 \\
29.5 \pm 0.2 \\
\end{array}$ & $\begin{array}{l}1 / 3 \\
33.5 \\
29.7 \pm 0.2 \\
\end{array}$ \\
\hline
\end{tabular}

1 "Cp means" should not be compared between different centers but only within the same center. ${ }^{2}$ IC: internal control supplied with the TIB MolBiol® kit. w/o: without. Cp: crossing point. Sd: standard deviation

\section{PCR methods}

The reference PCR methods were based on hybridization probes (Fluorescence Resonance Energy Transfer technology) for centers A, B and $\mathrm{D}$, and hydrolysis probe (TaqMan) for center $\mathrm{C}$. Centers A, B and C used a laboratory-developed real-time PCR targeting the non-coding repetitive sequence rep529 ${ }^{16}$ in the experimental conditions described by Reischl et al ${ }^{17}$ in centers A and B, Robert-Gangneux et al. ${ }^{18}$ in center $\mathrm{C}$ and Costa et al. ${ }^{19}$ in center D. The experiments were performed on a Light Cycler 480 (Roche $\AA$ ) in center A and C and Light Cycler 2.0 (Roche ${ }^{\circledR}$ ) in centers B and D (Table 1). In agreement with good laboratory practices, the laboratory-developed PCR assays included positive controls, negative controls, DNA extraction controls (human beta-globin gene revealed in SYBR green as described by Saiki et al. ${ }^{20}$ ) for center A, quantification of DNA by spectrophotometry for center B and DiaControl IDNA YD (Diagenode s.a. Liège, Belgium) for center C, and PCR inhibition internal controls (low concentration $T$. gondii DNA in a separate tube for center A, BacterioPhiX for center B and DiaControl IDNA YD (Diagenode) for center C). The TIB MolBiol $^{\circledR}$ assay (LightMix ${ }^{\circledR}$ Kit Toxoplasma gondii (EC) order no. 40-0217-32) was used according to the manufacturer's recommendations. It targets a 134-bp fragment from a repeated element of $T$. gondii genome (not specified by the manufacturer); the resulting PCR fragment of $T$. gondii is analyzed with LightCycler® Red 640 labeled probes. This kit includes a negative control (NTC), an internal control (IC) also named extraction control target (ECT) or spiked extraction control (sEC), which can be added to the sample before extraction $(10 \mu \mathrm{L})$ or in the PCR reaction mix $(0.5 \mu \mathrm{L})$, and a standard row made of target DNA in six different concentrations. The control reaction generates a product of $300 \mathrm{bp}$, detected using LightCycler® Red 690 labeled hybridization probes. The use of a color compensation file generated with the LightMix ${ }^{\circledR}$ Color Compensation 
HybProbe 530/640/690 kit (order no. 40-0318-00) is a prerequisite to detect the control reaction.

\section{Data and statistical analysis}

Crossing point $(\mathrm{Cp})$ values were calculated using the "absolute quantification/second derivative maxima" (LightCycler ${ }^{\circledR} 480$ Software release 1.5.1.62, Roche $\left.{ }^{\circ}\right)$. The performances of the PCR were evaluated by calculating the linear measuring range (regression analysis, $\mathrm{R}^{2}$ ) and the efficiency $\left(\mathrm{Eff}=10^{(-1 / \text { slope })}-1\right)$. Agreement and correlation between the two methods for the positive specimens were evaluated by Bland-Altman and correlation plots. Bland-Altman plots ${ }^{21}$ are a graphical representation of the difference of PCR crossing point $(\mathrm{Cp})$ values in abscissa plotted against the mean of $\mathrm{Cp}$ values in ordinate, here for all samples analyzed using a laboratory-developed method (Center A-C) and the commercial kit ${ }^{21}$.

\section{Results}

\section{Comparative assessment using standards for PCR detection}

Two centers (A and B) compared the TIB MolBiol ${ }^{\circledR}$ method and their reference diagnostic method by testing the standard of the NRC-T network ("TG25040, 1×10 4 parasites per mL, type II strain, Montpellier 2014") ${ }^{10}$. Between three and six reactions were used for testing each of the standard's concentrations $(10,000,1000,100,10,1$ and $0.1 T$. gondii genome equivalents $(\mathrm{T}) / \mathrm{mL}$ ) (Table 2). Results obtained using all methods were identical down to $1 \mathrm{~T} / \mathrm{mL}$, but slightly lower for the

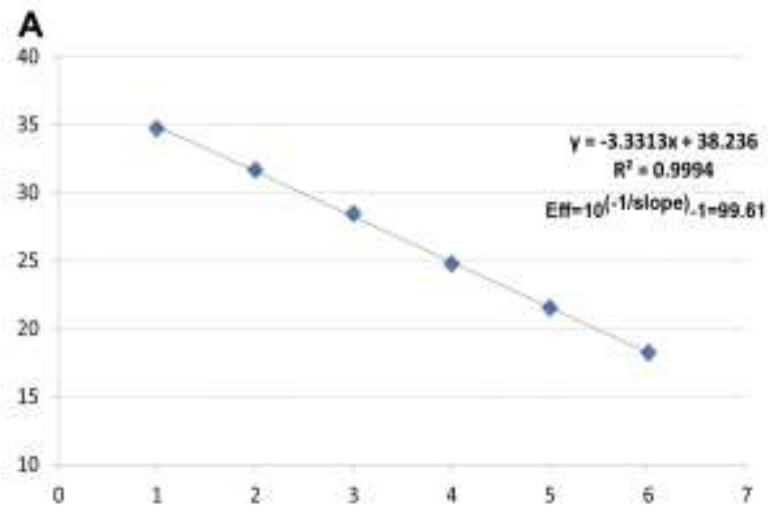

commercial kit when using the $0.1 \mathrm{~T} / \mathrm{mL}$ concentration (Table 2). The lower threshold of Toxoplasma DNA detection (defined as the lowest concentration where $>50 \%$ of the reactions remain positive) ${ }^{25}$ was $0.1 \mathrm{~T} / \mathrm{mL}$ for the laboratorydeveloped method of center $\mathrm{A}$, and $1 \mathrm{~T} / \mathrm{mL}$ for the laboratory-developed method of center B as well as the TIB MolBiol ${ }^{\circledR}$ method in both centers (Table 2 ). This threshold was not reached when the TIB MolBiol ${ }^{\circledR} \quad$ DNA standard was included (Supplementary Table 1). The relationship between the $\mathrm{Cp}$ and the DNA concentration was linear over $6 \log$ units $\left(\mathrm{r}^{2}>0.99\right)$ for both standards. The PCR efficiencies of the commercial kit were equivalent for the two standards $\quad(\mathrm{Eff}=93 \%$ and $99 \%$ respectively) (Figure 1). The TIB MolBiol ${ }^{\circledR}$ commercial kit includes an internal control (IC). The possibility of an internal competition between the IC and low concentrations of the target was investigated by testing the DNA standard both with and without the IC. In the 'with IC condition', IC was added in the PCR tube with the sample extracted DNA, and not added directly in the sample as an extraction control. No difference in sensitivity was observed whether using or not using the IC with the TIB MolBiol ${ }^{\circledR}$ method (Supplementary Table 1). Similarly, no difference was seen when testing the standard of the NRC-T with or without including this IC, still using the TIB MolBiol ${ }^{\circledR}$ method (Table 2). Of note, when testing the highest concentrations of Toxoplasma DNA, the IC was not amplified (Table 2 and Supplementary Table 1). This also occurred with clinical samples when the Cp was $<24$.

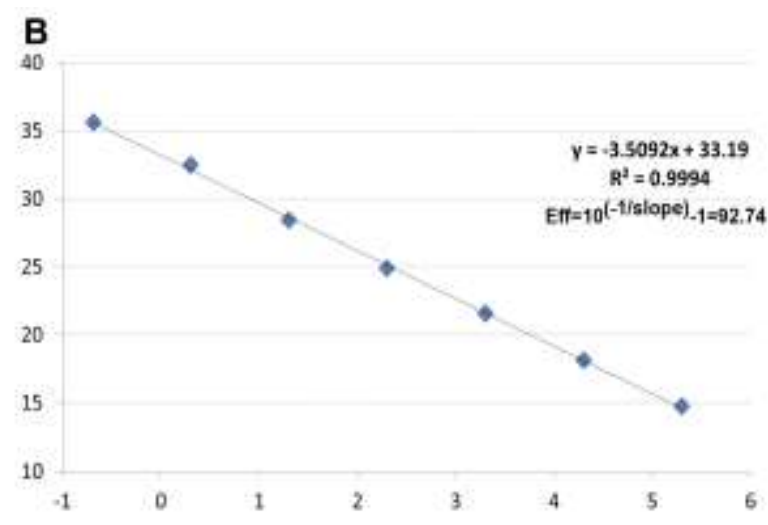

Figure 1. Linear measuring range and PCR efficiency from serial dilution assays. A. serial dilution assay from LightMix ${ }^{\circledR}$ Kit Toxoplasma gondii (EC). B. serial dilution assay from the NRC-Toxoplasma 

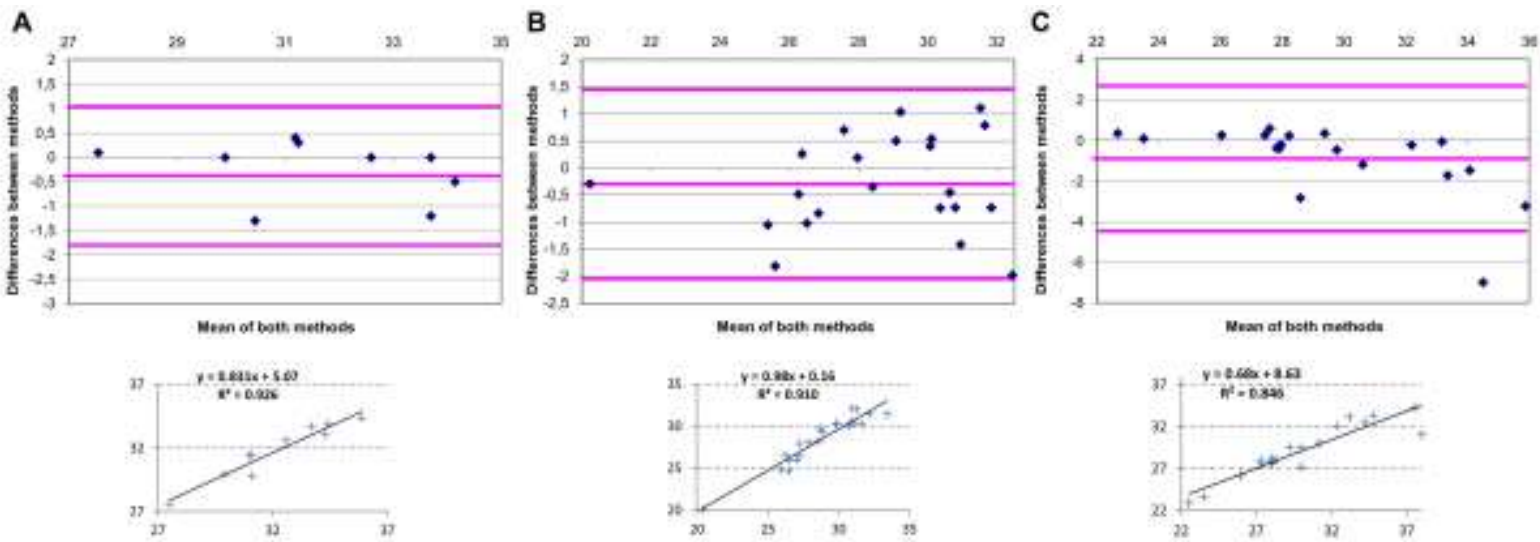

Figure 2. Bland-Altman and correlation plots representing the concordance between the Cp values obtained using laboratory-developed methods and the commercial kit for the molecular detection of T. gondii. Bland Altman plots for center A-C. The pink lines represent the means and \pm 1.96 standard deviations. Correlation plots: Cp values of the laboratory-developed methods were plotted against the values obtained with the commercial kit (Center A-C). Linear regressions with their equation and $\mathrm{R}^{2}$ values are presented for center A-C.

\section{Comparative assessment using External Quality Control samples}

Centers A-C tested 20 External Quality Control samples produced by the NRC-T; these were lyophilized spiked AF samples, of which 7 negative and 13 tittered at different concentrations, ranging from $100 \pm 15 \mathrm{~T} / \mathrm{mL}$ to $5 \pm 4 \mathrm{~T} / \mathrm{mL}$. The results obtained using TIB MolBiol ${ }^{\circledR}$ were in agreement with the expected results and each of the reference methods, with two exceptions. Indeed, Center C found two falsely negative results, one using the commercial kit and one using its own laboratorydeveloped method (Supplementary Table 2). The falsely negative result obtained by the routine method concerned a sample of spiked $\mathrm{AF}$ at $14 \pm 5 \mathrm{~T} / \mathrm{mL}$ sent in duplicate; the duplicate sample was found concordantly positive by the routine and the TIB MolBiol ${ }^{\circledR}$ methods. The other discrepant result, found falsely negative using TIB MolBiol®, was a spiked $\mathrm{AF}$ at $5 \pm 4 \mathrm{~T} / \mathrm{mL}$ that was sent in triplicate, the remaining three samples were found concordantly positive by the routine and the TIB MolBiol ${ }^{\circledR}$ methods. At such a low concentration, the Poisson law may apply and finding two out of three samples positive should be considered as acceptable.

\section{Comparative assessment using clinical samples}

In total, in the four centers, 133 clinical samples were included in the study, issued from DNA collections or prospectively tested (cf. Materials \& Methods and Supplementary Table 2). The results were concordant between the commercial kit and the reference method for 130/133 (97.7\%) samples. These included 59 negative and 74 positive samples (Table 3 and Supplementary Table 2).

Table 3. Consistency between the TIB MolBiol ${ }^{\circledR}$ and reference methods using characterized clinical samples

TIB MolBiol

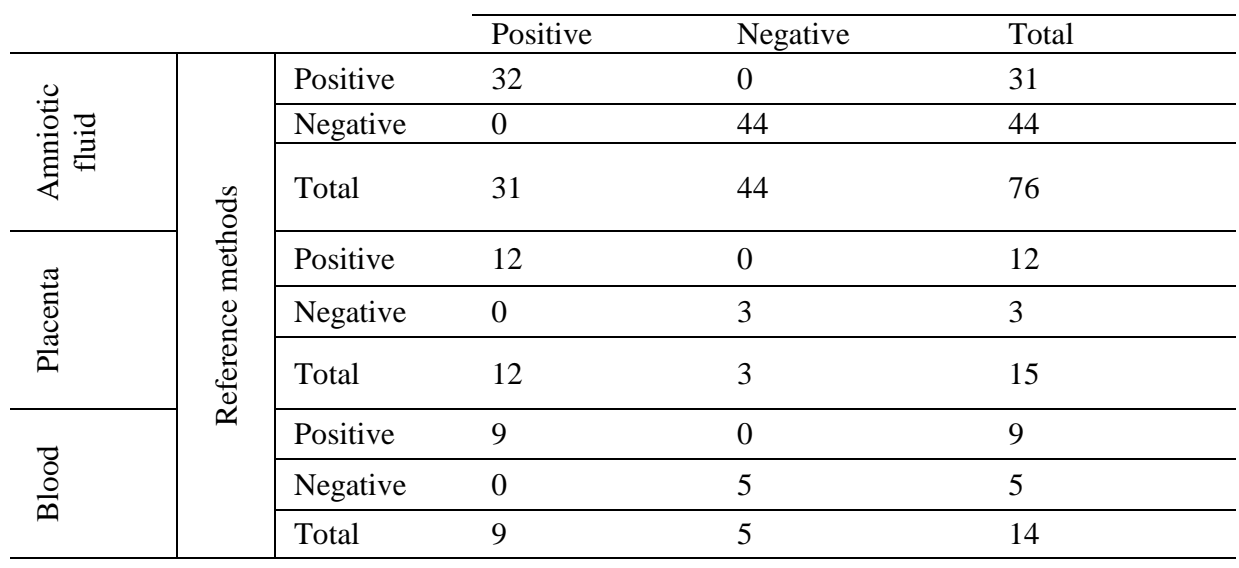




\begin{tabular}{|c|c|c|c|c|}
\hline \multirow{3}{*}{ 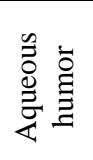 } & Positive & 6 & 2 & 8 \\
\hline & Negative & 0 & 0 & 0 \\
\hline & Total & 6 & 2 & 8 \\
\hline \multirow{3}{*}{ 崖 } & Positive & 2 & 0 & 2 \\
\hline & Negative & 1 & 4 & 5 \\
\hline & Total & 3 & 4 & 7 \\
\hline \multirow{3}{*}{$\sqrt{\tilde{U}}$} & Positive & 6 & 0 & 6 \\
\hline & Negative & 0 & 1 & 1 \\
\hline & Total & 6 & 1 & 7 \\
\hline \multirow{3}{*}{ 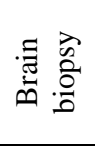 } & Positive & 5 & 0 & 5 \\
\hline & Negative & 0 & 0 & 0 \\
\hline & Total & 5 & 0 & 5 \\
\hline \multirow{3}{*}{ 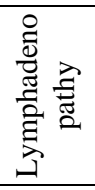 } & Positive & 1 & 0 & 1 \\
\hline & Negative & 0 & 0 & 0 \\
\hline & Total & 1 & 0 & 1 \\
\hline \multirow{3}{*}{ 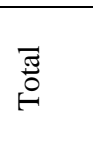 } & Positive & 72 & 2 & 74 \\
\hline & Negative & 1 & 58 & 59 \\
\hline & Total & 73 & 60 & 133 \\
\hline
\end{tabular}

The three discrepant results were found in center A and $\mathrm{D}$; they were made of two falsely negative results of TIB MolBiol ${ }^{\circledR}$ (center A and D) and one falsely positive result of TIB MolBiol@ (center D). The first false negative of TIB MolBiol ${ }^{\circledR}$ were found inconstantly positive (1/6 PCR reactions) in routine and negative using TIB MolBiol ${ }^{\circledR}(0$ positive PCR/1 PCR reaction performed). It concerned an aqueous humor from a chorioretinitis confirmed by a positive comparative immunoblot and by a concordant positive PCR using both assays in the vitreous. This case highlights how the parasite burden can be extremely low. The second case was also an aqueous humor with a low parasite burden $(3 / 3$ positive PCR reactions in routine $v s 0 / 1$ by TIB MolBiol@). Of note, in both cases, TIB MolBiol ${ }^{\circledR}$ was performed in simplicate due to the low volume of extracted DNA in this kind of samples. The third discrepancy was a BALF sample (center $\mathrm{D})$, positive in 1 out of 3 reactions $(\mathrm{Cp}=35)$ using the kit but negative using the laboratorydeveloped method (0/4 PCR reactions); since toxoplasmosis was clinically ruled out in this patient, this likely represents a falsely positive result from the TIB MolBiol® assay.

The concordance between the $\mathrm{Cp}$ values obtained using laboratory-developed methods and the commercial kit for the molecular detection of $T$. gondii was assessed. Ten concordantly positive samples analyzed in center A, 22 in center B and 19 in center $\mathrm{C}$ were included in the study. The Bland Altman plots and linear regression showed very good agreement with a single sample outside the \pm 1.96 standard deviation area and a high $\mathrm{R}^{2}$ (Figure 2).

\section{Discussion}

Commercial kits are now widely used for the molecular diagnosis of toxoplasmosis. Indeed, they most often offer convenient turnkey protocols which may be an advantage for the accreditation of medical microbiology laboratories. However their performances cannot be taken for granted and should be analyzed by independent expert networks. All participating centers belong to the "Molecular Biology Pole" of the NRC-T; they are regional reference centers for the molecular diagnosis of toxoplasmosis, and all laboratorydeveloped methods have been published ${ }^{2,18,19,22,23}$. Participating centers compared the TIB MolBiol ${ }^{\circledR}$ method with their own laboratory-developed method used in routine diagnosis. For this, (i) the standard lyophilized preparation of $T$. gondii used as a common standard within the NRC-T network ${ }^{10}$, and (ii) 133 patients samples obtained in various clinical settings were used. First of all, the respect by this PCR assay of essential rules was verified. In agreement with laboratory quality management, TIB MolBiol ${ }^{\circledR}$ included a negative control and an internal control (IC). Of note, we actually added this control in the PCR reaction mix rather than before DNA extraction. This attitude is frequently found in centers being part of a shared microbiology technical platform. Indeed, a single extraction control is used for all the PCR assays and target-specific positive controls are used as IC to check for the presence of inhibitors. The kit also included a standard row to estimate the quantity of the target sequence in clinical samples. TIB MolBiol ${ }^{\circledR}$ is the first Toxoplasma commercial kit 
including hybridization probes (FRET). The use of hybridization probes allows amplified fragments to be analyzed using melting curves, which is a major advantage over hydrolysis probes ${ }^{24}$, but does not prove to be particularly useful in routine practice. This implies that this kit was developed solely for the Roche ${ }^{\circledR}$ LightCycler ${ }^{\circledR}$ devices. Regarding practicality, the major drawback of this kit is that it necessitated the reconstitution of several reagents, including $\mathrm{MgCl} 2$; in addition, a 10X PCR master mix had to be purchased separately. Finally, it did not include heat-labile Uracil-N-Glycosylase to limit carryover DNA contamination. However, since the master mix is not included, this step can be added using a master mix which contains uracil instead of thymidine; one must then check the absence of effect of this on the sensitivity of the assay.

In total, taking into account the twenty EQA samples and the 133 clinical samples, the sensitivity and specificity of the routine methods were respectively $86 / 87$ (98.9\%) and 66/66 (100\%). Sensitivity and specificity of the TIB MolBiol ${ }^{\circledR}$ kit were respectively $84 / 87=98.1 \%$ and $65 / 66=98.5 \%$. This was not statistically different from the figures obtained using the routine methods. The use of the commercial PCR assay TIB MolBiol LightMix ${ }^{\circledR}$ Toxoplasma gondii therefore proved satisfactory for the diagnosis of toxoplasmosis in diverse clinical settings: congenital, ocular and disseminated toxoplasmosis. Its performances, using a wide variety of clinical samples, were equivalent to those of reference laboratory-developed assays. Yet, the analytical sensitivity threshold determined here was 10-fold higher than that of the most sensitive method of the NRC-T $(0.1 \mathrm{~T} / \mathrm{mL} v s 1 \mathrm{~T} / \mathrm{mL})$. For this reason, it must be noted that falsely negative results may be observed for very low parasitic loads, particularly if a single PCR reaction is performed. The supply with this commercial kit of an internal control which does not appear to compete nor interfere with the detection of low parasite concentrations is a positive point. Finally, this kit offers the possibility of an absolute quantification of the parasitic load, which, in view of the possible correlation with the severity of the disease ${ }^{19,26}$, might be interesting; however, the DNA standard allowing quantifying parasitic loads is expressed as a number of target copies, and not in Toxoplasma per mL, which may hinder inter-laboratory comparisons and interpretation since the existing studies examined the parasitic loads in parasites per $\mathrm{mL}$.

\section{Acknowledgements}

We thank Jean-Marc Costa for its contribution in the routine diagnosis assay of center D. We thank Sylvie Douzou, Ghyslaine Serres and Bounleth Sanichanch (Montpellier), Valérie Martin (Grenoble), Pauline Comacle (Rennes) and Géraldine Desserre (Bordeaux) for their technical assistance. We acknowledge the financial support of "Santé Publique France" through the French National Reference Center for Toxoplasmosis, and of the RSI Assurance Maladie Professions Libérales-Provinces, C.A.M.P.L.P. for funding the LightCycler 480 real-time thermocycler (Roche®) in Montpellier.

\section{References}

1. Montoya JG, Liesenfeld O: Toxoplasmosis. Lancet 2004, 363:1965-1976.

2. Sterkers $Y$, Pratlong $F$, Albaba $S$, Loubersac J, Picot MC, Pretet $V$, Issert E, Boulot $P$, Bastien P: Novel interpretation of molecular diagnosis of congenital toxoplasmosis according to gestational age at the time of maternal infection. J Clin Microbiol 2012, 50:3944-3951.

3. Robert-Gangneux F, Belaz S: Molecular Diagnosis of Toxoplasmosis in Immunocompromised Patients. Curr Opin Infect Dis 2016, 29:330-339.

4. Roux G, Varlet-Marie E, Bastien P, Sterkers Y: Evolution of Toxoplasma-PCR methods and practices: a French national survey and proposal for technical guidelines. Int J Parasitol 2018, 48:701-707.

5. Morelle C, Varlet-Marie E, Brenier-Pinchart $M P$, Cassaing $S$, Pelloux $H$, Bastien $P$, Sterkers $Y$ : Comparative assessment of a commercial kit and two laboratory-developed PCR assays for molecular diagnosis of congenital toxoplasmosis. J Clin Microbiol 2012, 50:3977-3982.

6. Filisetti $D$, Sterkers $Y$, Brenier-Pinchart $M P$, Cassaing S, Dalle F, Delhaes L, Pelloux H, Touafek F, Varlet-Marie E, Yera H, Candolfi E, Bastien P: Multicentric comparative assessment of the bio- evolution Toxoplasma gondii detection kit with eight laboratory-developed PCR assays for molecular diagnosis of congenital toxoplasmosis. J Clin Microbiol 2015, 53:29-34.

7. Robert-Gangneux $F$, Brenier-Pinchart $M$, Yera $H$, Belaz S, Varlet-Marie E, Bastien P: Evaluation of Toxoplasma ELITe MGB Real-Time PCR Assay for Diagnosis of Toxoplasmosis. J Clin Microbiol 2017, 55:1369-1376.

8. Döşkaya $M$, Pullukçu $H$, Karakavuk $M$, Şahar $E$, Taşbakan M, Taşbakan M, Yılmaz M, Can H, Döşkaya A, Gürüz A: Comparison of an in House and a Commercial Real-Time Polymerase Chain Reaction Targeting Toxoplasma Gondii RE Gene Using Various Samples Collected From Patients in Turkey. BMC Infect Dis 2019, 19:1042.

9. Romand $S$, Chosson $M$, Franck J, Wallon $M$, Kieffer F, Kaiser K, Dumon H, Peyron F, Thulliez P, Picot S: Usefulness of quantitative polymerase chain reaction in amniotic fluid as early prognostic marker of fetal infection with Toxoplasma gondii. Am J Obstet Gynecol 2004, 190:797-802.

10. Varlet-Marie E, Sterkers $Y$, Brenier-Pinchart MP, Cassaing S, Dalle F, Delhaes L, Filisetti D, Pelloux H, 
Touafek F, Yera H, Bastien P: Characterization and multicentric validation of a common standard for Toxoplasma gondii detection using nucleic acid amplification assays. J Clin Microbiol 2014, 52:39523959.

11. Lebech $M$, Joynson DH, Seitz HM, Thulliez $P$, Gilbert RE, Dutton GN, Ovlisen B, Petersen E: Classification system and case definitions of Toxoplasma gondii infection in immunocompetent pregnant women and their congenitally infected offspring. European Research Network on Congenital Toxoplasmosis. Eur J Clin Microbiol Infect Dis 1996, 15:799-805.

12. Martino R, Maertens J, Bretagne S, Rovira M, Deconinck E, Ullmann AJ, Held T, Cordonnier C: Toxoplasmosis after hematopoietic stem cell transplantation. Clin Infect Dis 2000, 31:1188-1195.

13. Greigert $V$, Di Foggia E, Filisetti D, Villard $O$, Pfaff A, Sauer A, Candolfi E: When Biology Supports Clinical Diagnosis: Review of Techniques to Diagnose Ocular Toxoplasmosis. Br J Ophthalmol 2019, 103:10081012.

14. Hohlfeld P, Daffos F, Costa JM, Thulliez P, Forestier F, Vidaud M: Prenatal diagnosis of congenital toxoplasmosis with a polymerase-chain-reaction test on amniotic fluid. N Engl J Med 1994, 331:695-699.

15. Delhaes L, Filisetti $D$, Brenier-Pinchart MP, Pelloux $H$, Yera $H$, Dalle $F$, Sterkers $Y$, Varlet-Marie $E$, Touafek F, Cassaing S, Bastien P: Freezing and storage at -20 degrees $C$ provides adequate preservation of Toxoplasma gondii DNA for retrospective molecular analysis. Diagn Microbiol Infect Dis 2014, 80:197-199.

16. Homan WL, Vercammen M, De Braekeleer J, Verschueren $\mathrm{H}$ : Identification of a 200 - to 300 -fold repetitive 529 bp DNA fragment in Toxoplasma gondii, and its use for diagnostic and quantitative PCR. Int J Parasitol 2000, 30:69-75.

17. Reischl U, Bretagne S, Kruger D, Ernault P, Costa JM: Comparison of two DNA targets for the diagnosis of Toxoplasmosis by real-time PCR using fluorescence resonance energy transfer hybridization probes. BMC Infect Dis 2003, 3:7.
18. Robert-Gangneux F, Dupretz P, Yvenou C, Quinio D, Poulain P, Guiguen C, Gangneux JP: Clinical relevance of placenta examination for the diagnosis of congenital toxoplasmosis. Pediatr Infect Dis J 2010, 29:33-38.

19. Costa JM, Ernault P, Gautier E, Bretagne S: Prenatal diagnosis of congenital toxoplasmosis by duplex real-time PCR using fluorescence resonance energy transfer hybridization probes. Prenat Diagn 2001, 21:8588.

20. Saiki RK, Scharf S, Faloona F, Mullis KB, Horn GT, Erlich HA, Arnheim N: Enzymatic amplification of beta-globin genomic sequences and restriction site analysis for diagnosis of sickle cell anemia. Science 1985, 230:1350-1354.

21. Bland JM, Altman DG: Statistical methods for assessing agreement between two methods of clinical measurement. Lancet 1986, 1:307-310.

22. Sterkers $Y$, Ribot J, Albaba S, Issert E, Bastien P, Pratlong F: Diagnosis of congenital toxoplasmosis by polymerase chain reaction on neonatal peripheral blood. Diagn Microbiol Infect Dis 2011, 71:174-176.

23. Brenier-Pinchart $M$, Capderou $E$, Bertini $R$, Bailly S, Fricker-Hidalgo $H$, Varlet-Marie E, Murat J, Sterkers Y, F T, P B, H P: Molecular Diagnosis of Toxoplasmosis: Value of the Buffy Coat for the Detection of Circulating Toxoplasma Gondii. Diagn Microbiol Infect Dis 2015, 82:289-291.

24. Navarro E, Serrano-Heras G, Castaño MJ, Solera J: Real-time PCR detection chemistry. Clin Chim Acta 2015, 439:231-250.

25. Sterkers $Y$, Varlet-Marie E, Cassaing $S$, BrenierPinchart MP, Brun S, Dalle F, Delhaes L, Filisetti D, Pelloux $\mathrm{H}$, Yera $\mathrm{H}$, Bastien P: Multicentric comparative analytical performance study for molecular detection of low amounts of Toxoplasma gondii from simulated specimens. J Clin Microbiol 2010, 48:3216-3222.

26. Yamamoto L, Targa L, Sumita L, Shimokawa P, Rodrigues J, Kanunfre K, Okay T: Association of Parasite Load Levels in Amniotic Fluid With Clinical Outcome in Congenital Toxoplasmosis. Obstet Gynecol 2017, 130:335-345. 


\section{Supplementary materials}

Supplementary Table S1. Comparative testing of the TIB MolBiol ${ }^{\circledR}$ DNA standard including or not the internal control

\begin{tabular}{|c|c|c|c|c|c|c|c|}
\hline & Target molecules in $5 \mu \mathrm{L}^{\mathrm{a}}$ & $10^{6}$ & $10^{5}$ & $10^{4}$ & $10^{3}$ & $10^{2}$ & 10 \\
\hline TIB MolBiol with IC & $\mathrm{N}$ & $6 / 6$ & $6 / 6$ & $6 / 6$ & $6 / 6$ & $6 / 6$ & $6 / 6$ \\
\hline $\mathrm{Eff}=106 \%$ & Cp mean \pm sd & $17.3 \pm 0.7$ & $21.0 \pm 0.5$ & $24.2 \pm 0.4$ & $27.6 \pm 0.9$ & $30.4 \pm 0.4$ & $33.4 \pm 0.5$ \\
\hline $\mathrm{R}^{2}=0.96$ & IC Cp mean \pm sd & Neg & Neg & Neg & $28.1 \pm 0.2$ & $27.8 \pm 0.2$ & $28.1 \pm 0.1$ \\
\hline $\begin{array}{l}\text { TIB MolBiol w/o IC } \\
\text { Eff }=102 \% \\
R^{2}=0.99\end{array}$ & $\begin{array}{l}\mathrm{N} \\
\mathrm{Cp} \text { mean } \pm \mathrm{sd}\end{array}$ & $\begin{array}{l}6 / 6 \\
17.1 \pm 0.1\end{array}$ & $\begin{array}{l}6 / 6 \\
20.4 \pm 0.2\end{array}$ & $\begin{array}{l}6 / 6 \\
23.7 \pm 0.2\end{array}$ & $\begin{array}{l}6 / 6 \\
26.7 \pm 0.1\end{array}$ & $\begin{array}{l}6 / 6 \\
31.0 \pm 0.1\end{array}$ & $\begin{array}{l}6 / 6 \\
33.0 \pm 1.1\end{array}$ \\
\hline
\end{tabular}

${ }^{\mathrm{a}}$ Data from the supplier. Cp : crossing point. Sd : standard deviation.

\section{$6 \quad$ Supplementary Table S2. Raw data}

7 Spreadsheet file, discordant PCR data are highlighted in yellow. Available online only. 